\title{
for(e)dialogue
}

Department of Media and Communication

Volume 1, Issue 1: New Directions in Media Research 2015

A review on China's soft power projection through its transnational media institutions: Conveying discourse of economic responsibilities in media 'going-out'

Xin Zhao

(p. 27-39)

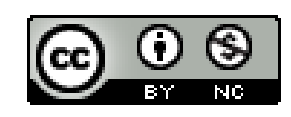

This work is licensed under a

Creative Commons Attribution- Non Commercial 4.0 International License

March 2016 
Volume 1, Issue 1: New Directions in Media Research 2015

\section{A review on China's soft power projection through its transnational media institutions: Conveying discourse of economic responsibilities in media 'going-out'}

\section{Xin Zhao}

Abstract: This conference paper provides a systematic review of previous literature on China's media 'going-out' project, one of China's soft power initiatives. The project was launched to mainly counteract the media imperialism and the China threat theory, and disseminate China's responsible power claim, the core value of China's soft power practice. Particularly, China tries to portray its responsibilities in economy. But it is under-studied how China's transnational media represent China's responsible power claim during the media 'going-out' project. It is necessary to bridge this academic gap by examining relevant media texts and production procedures based on a comprehensive understanding of the Chinese conceptions of responsibility and the Western conceptions of China's responsibility.

Keywords: transnational media, responsibility, China, soft power, discourse

\section{Introduction}

Joseph Nye (1990) coined the term 'soft power' to describe a country's ability to co-opt rather than coerce in the process of shaping the preferences and long-term attitudes of the public in the receiving country in order to facilitate the missions of the practicing country. The term and basic idea of soft power not only quickly gained popularisation among Chinese politicians, scholars, pundits, and journalists, but also witnessed China's extensive practices. Among various soft power resources, media serves as a quicker conduit in delivering a country's messages. In 2009, China emphasised the role of media in its soft power projection by launching the media 'going-out' project. This paper provides a systematic review of sufficient studies pertaining to China's media 'going-out' project in order to see to what extent the project has been investigated. If already thoroughly discussed, then future research agendas need to be generated; if limited theoretical and empirical underpinnings are searched out, then it will be timely to contribute data to studies of this project, one of the key movements of China's soft power practice.

This paper firstly focuses on the overall context of the project and then its key findings and approaches. It aims to synthesise the current research status of the project and locate its academic gaps. During reviewing, as to the process of studies retrieving, an exhaustive sensitive search by keywords, such as 'China' \& 'soft power' and 'China' \& 'media going-out', and their synonyms was 
Volume 1, Issue 1: New Directions in Media Research 2015

conducted first in several complementary databases including Communication Source, Google Scholar, and e-journals accessed through Bangor University Library. Then the located studies from different disciplines and in different languages were sifted through and only the most relevant studies were kept. It is important to highlight that there were no more than ten studies focusing on China's media 'going-out' project directly, but much more on China's soft power. The review firstly expanded its search by snowballing the references in the limited studies and secondly narrowed down its focus on media in the numerous studies of China's soft power. Then the appraising of studies were based on their relevance to the research questions and their validity in empirical investigation and data analysis. Lastly, a narrative synthesis was applied to analyse the relationships within and between studies and assess the robustness of the evidence (Petticrew and Roberts, 2006). Through the review, this paper concludes that China's launch of media 'going-out' project was under the pressure of the media imperialism and the negative China threat and irresponsibility theses. With its own transnational media institutions, China not only tries to counteract the ideological attack, but also voice its benign messages as a responsible power in areas like economy. In order to understand China's media 'going-out' project and outbound communication from a microscopic perspective, an examination of relevant media texts and media production procedures is necessary. However, this is a quite under-studied topic that needs special academic focus.

\section{The Overall Context}

"We have to assure countries around us, including the United States that we have no aggressive intentions, that we want a peaceful environment to concentrate on economic development. We have to have others believe us, and that is a problem." (quoted in Shirk, 2007, p.106)

The above statement, coming from Major General Pan Zhenqiang in China's National Defence University, indicates clearly the objective of China's soft power projection and that is to counter the Western negative perceptions of China and to disseminate its benign messages. Therefore, China's major transnational media institutions are deployed as conduits. In particular, China launched the

media 'going-out' project in 2009 and emphasised the role of transnational media institutions in delivering and branding China's national image to the world ( $\mathrm{Hu}$ and Ji, 2012). Literally, 'going-out' refers to outbound communication from China. Although the wording is grammatically awkward to some extent, the current research keeps it for the reasons that firstly, it is a political statement from the Chinese government, and secondly, it is used in many widely cited academic works, such as $\mathrm{Hu}$ and Ji (2012) and Svensson (2013). It is worth mentioning particularly why the year 2009 is chosen as the starting point of this project, on which there is actually no consensus since no official document 
Volume 1, Issue 1: New Directions in Media Research 2015

clearly indicates it. Although one report (Wang, 2012) says that the 'going-out' project of China's press and publication began in 2003, some scholars (e.g. Zhao, 2013; Hu and Ji, 2012) maintain that the 'going-out' of media initiated from 2009. This year witnessed some major movements of China's media, such as China Central Television's revamp of the 24-hour English-language news service CCTV News, Xinhua News Agency's launch of the 24-hour English-language television channel CNC World, and China Daily's expansion in overseas distribution and bureaus (Zhao, 2013; Hu and Ji, 2012). Therefore, the current study also considers that the project started from 2009. This chapter casts light on previous studies on the context of the project's launch and development from both external and internal perspectives. It particularly focuses on the contradiction between the China threat theory and China's claim to be a responsible power.

\subsection{External factors: media imperialism and China threat theory}

China's launch of media 'going-out' project is driven by external pressure emitting from the media imperialism and the China threat theory (Hu, Zhang and Ji, 2013). Media imperialism brings massive information flow and values originated from Western mainstream media to the Chinese market, while the China threat theory is more like a direct ideological attack on China. Accordingly, the project desires to challenge the Western media giants with China's own media conglomerates and to reverse the amplification of negative reports by Western media (Hu, Zhang and Ji, 2013).

\subsubsection{Media imperialism}

Media imperialism developed as a result of technical innovations that increasing flow of information was transferred with no border barriers during the Cold War period (Volkmer, 1999). Galtung and Ruge (1965) contribute to the establishment of the concept of media imperialism by pointing out the unbalanced news flow from centre to periphery countries. The UNESCO project carried out by Sreberny-Mohammadi et al. (1985) proved that major wire services exerted dominant influence on setting international news agenda and deciding ways of news presentation. Nevertheless, with the proliferation of digital technologies and media privatisation and deregulation, erstwhile passive information recipients are getting more involved in the worldwide information flow, resulting in the contra-flows, such as news from the Arab news network Al Jazeera and the Chinese television channel Phoenix (Thussu, 2010; Volkmer, 1999). Along with these newly emerging news media, the national gate-keeping policies and the local audience's behaviours all undermine, to a certain degree, the dominant influence of media imperialism (Chadha and Kavoori, 2000). The new phenomenon induced other positive arguments, such as the new public sphere theory which suggests that the international communication has enabled diverse realities and values to coexist in 
Volume 1, Issue 1: New Directions in Media Research 2015

the global public platform (Castells, 2008; Volkmer, 1999). However, the parallelism of flows and contra-flows does not necessarily result in a "diverse" or "democratic" world (Thussu, 2010, p.234). This study agrees that the media imperialism is still exerting influence on the global media and communication environment and it is closely related with the underlying disparity in political and economic domains (Boyd-Barrett, 2010; Schiller, 2010; Thussu, 2010). The contra-flows, such as China's transnational media channels, are actually signs of contradictions from peripheral countries.

\subsubsection{China threat theory}

The evolution of the China threat theory can be divided into three stages (Jin, 2009). It first appeared as the term 'Yellow Peril' coined by German Emperor Wilhelm II to refer to the dangerous Asian people at the end of the 19th century and the beginning of the 20th century, and then as 'Red Scare' promoted by Western countries as an expression of anti-communist fear in the 1950s when the new China was founded (Ren, 2015; Jin, 2009). In the 1990s when the Cold War ended, the theory prevailed again, aroused by countries like Japan and America, as a result of China's reform and opening up and ascending economy (Ren, 2015). The theory repeatedly appeared in Western dominant media, such as US elite newspapers, to indicate that China's rise may pose economic/trade, military/strategic, and political/ideological threats to regional and global stability (Yang and Liu, 2012; Zhang, 2008). It is also widely discussed in Western scholarly works and government policymaking in countries like the United States ( $\mathrm{Wu}, 2007)$. This research chooses not to deliberately separate the views expressed in different channels since they may have mutual influence. Since 2005, the China responsibility theory has gained more momentum. It is originated from, as generally accepted, the term 'responsible stakeholder' raised by Robert Zoellick (2005), the former U.S. Deputy Secretary of State (Chen, 2009; Deng, 2009). Literally, it means that China should take its responsibilities in international affairs. To take a closer examination, the theory contains the implications that China is an irresponsible country, it should shoulder more responsibilities, and it should stay inside of the current international system (Ma, 2007). Overall, it shares the same kernel with the China threat theses that both are advocated to condemn, restrain, and regulate China (Ma, 2007).

Among all the domains that China is progressing prominently, economy is perhaps the area that has generated most fear and suspicion from the international community (Wu, 2007; Ding, 2006). Evidence is shown in the empirical examination of the coverage of China threat in the US print media over a 15-year period (1992-2006) that perceptions of China as an economic/trade threat remained stable with a clear uptick in recent years compared with perceptions of China as a political/ideological or a military/strategic threat (Yang and Liu, 2012). Three major reasons 
Volume 1, Issue 1: New Directions in Media Research 2015

contribute to the wide-ranging fear of China's economy: first, China may follow the path left by Western dominant powers that power transition stimulates conflict; second, China has a completely different political and ideological environment in which its economy is developing and that is also a potential point of conflict; third, China possesses rich resources of culture, population, and territory, which may turn out to be the foundation of its refusal to be a status quo power (Chen, 2009). What's more, according to Bernstein and Munro (1997, p.19), China's ambition to dominate Asia is propelled by "nationalist sentiment, a yearning to redeem the humiliations of the past, and the simple urge for international power". In a word, in the view of other countries, China's position as an ambitious country with strong national strength on one hand, and as a transitional country with victimhood sentiments on the other hand, is the main reason for its threatening gesture.

Drawing from this complicated identity, what are the exact economic threats, seen from the Western perspective, that China is likely to pose to the world? Firstly, China's booming economy, increasing national strength, and deep-rooted victimhood ideology can result in economic manipulation and this may be the major concern in most relevant debates (Al-Rodhan, 2007). For example, China's economic ascent has resulted in, or has the potential to continue to cause, violations of intellectual property rights, a loss of manufacturing and industrial jobs in Western countries, furious energy competition, and environmental problems (Yang and Liu, 2012; Breslin, 2010; Al-Rodhan, 2007; Broomfield, 2003). The second potential threat is much less discussed in the China threat theory. China's uncertain internal situation is a threat to China itself, which is also a threat to the outside world as a result of ripple effects (Al-Rodhan, 2007). The uncertainties include China's blurred economic future and potential social instability caused by immense income inequality and poverty (Al-Rodhan, 2007). In a word, considering China's political, social, and ideological positions, its potential threats in the eyes of other countries not only involve its possible ambition to strive for hegemony, but can also be expanded to include the potential instability coming from China's internal issues in this era of globalisation (Al-Rodhan, 2007).

However, there are also opponents of the China threat theory. Through an analysis of China's position, the liberal optimists hold contrasting opinions upon China's economic growth compared with those of pessimistic realists. Externally, China is a member of the international community and it is constrained by the global market so that it is more inclined to cooperate with other members rather than generate conflict or isolation (Breslin, 2010; Liang, 2007; Broomfield, 2003; Roy, 1996). For example, China is seen as showing "stubborn commitment" to the existing trade system during its accession, learning, and socialisation in the World Trade Organisation (Scott and Wilkinson, 2013, p.782). What is more, their positioning of China does not cast light on China 
Volume 1, Issue 1: New Directions in Media Research 2015

alone but measures its actions according to a certain standard in a wider environment. For instance, as to the cheap labour issue, China is not the only developing nation that is chosen as a manufacturing factory and also not the only reason that results in the decline of manufacturing jobs in developed countries (Al-Rodhan, 2007). Internally, China as a historically benign and nonimperialistic country is likely to pay more attention to domestic social problems and it will spare little effort to pose threats to other countries aggressively (Roy, 1996).

It can be concluded that whether the ascending China is a threat or not is largely a matter of position and identity, no matter whether the threats (or not) are postulated according to China's previous actions or purely out of imagination. However, the proponents of the China threat theory are supported by their positioning of China as a country with strong hard power, special political system and social structure, and firmly embedded victimhood sentiments. While the opponents recognise China as a member of the globalised world, a normal member sharing universal development standards in the wider world, and a benign country in nature. It is because of the vague and non-uniform positions of China that both sides of the China threat theory have the deficiency of overgeneralisation. A definition of China as a threat or not should, first of all, clarify its position, which is the result of complicated internal and external sociocultural factors.

In summary, as one of China's key initiatives of soft power practice, the media 'going-out' project particularly targets at reversing the media imperialism and more importantly, the discourse of China's potential threats and irresponsibility advocated by Western countries. In response, China claims itself as a responsible power.

\subsection{Internal factor: the claim to be a responsible power}

China is fighting against the Western world's unfavourable depictions, and at the same time, it is trying to portray itself as, and persuade foreign audiences that China is, a responsible power via its own voices and perspectives through its own news media channels. China's persuasion and attraction as a responsible power is the overarching dimension of China's soft power practice (Kalathil, 2011; deLisle, 2010). Among a range of domains, China is most eager to demonstrate its sense of responsibility in global economic issues $(\mathrm{Gao}, 2013)$. Its promise as a responsible economic partner is also the core of China's doctrines of constructing a harmonious world and insisting a peaceful rise (d'Hooghe, 2010). Being economically responsible means that China's economic rise neither attempts to threaten the current international order nor targets at any member of the global community (Lye, 2010). 
Volume 1, Issue 1: New Directions in Media Research 2015

It is truly confusing to face the two terms, the China responsibility theory and China as a responsible power. However, they are intrinsically different in the following aspects. Firstly, they have different times of appearance. The China responsibility theory started to gain attention from 2005 when Zoellick raised the term responsible stakeholder. However, China's claim to be a responsible power began to take shape in the 1990s, although there are dissents about its origin. Some scholars contend that it began to spread in China in the mid-1990s as an acceptance of the language from America's (Clinton administration) speech of China policies (Deng, 2015; Shirk, 2007). One piece of evidence is China's explicit description of itself as a responsible power in the White Paper of foreign affairs in 1999 (see Gao, 2013). Some believe that it is an idea that originated from China itself (Yeophantong, 2013). For example, in 1997, the then Chinese President Jiang Zemin firstly mentioned the international responsibility of China, as a big power, in a speech to the Russian State Duma (Jiang, 1997). China's responsible role is a construction of various discourses so that neither Western nor Chinese language of China's responsibility should be ignored. Secondly, the China responsibility theory is basically a deviant of the former China threat theory and both are meant to restrict China's development, whereas China's own claim to be a responsible power is based on China's own developmental objectives. However, the norms of responsibility that China is claiming to pursue are likely to have Western derivation as explained previously.

Existing studies on China's role as a responsible power and its responsibilities in economy are mostly conducted from the perspective of international relations and politics (Deng, 2015; Yeophantong, 2013; Zhang and Austin, 2013; Zhao, 2010; Gill, 2007; Shirk, 2007). They try to present China's actions in international relations and politics and then interpret, judge, and define if they are responsible based on certain, but not universally accepted, standards. For example, from the observation of Susan Shirk, China's endeavours to be a responsible power can be primarily detected from three domains: accommodating its neighbours, engaging in cooperation in multilateral organisations, and enhancing its economic attractions to cultivate friendly relations (Shirk, 2007). Based on these and other actions, China's responsible role is generally concluded into two facets. Firstly, a state should not only actively participate in domestic development, but also in international affairs that are pertaining to an international community member's absolute liability and the world's advancing trend, taking both national interests and global benefits into consideration. Secondly, a state should not only act as an insider but also a formulator of the international system (Gao, 2013; Xu, 2010; Xia, 2001). Similar with the vagueness of the China threat theory, China's claim to be a responsible power is also implicit politically and morally (Zhang and Austin, 2013). China's position or identity, either as a good neighbour or as an active organisation participant, is defined variously in 
Volume 1, Issue 1: New Directions in Media Research 2015

different scholarly works so that the standard of responsibility is also inconsistent. This leads to difficulties in defining whether China's actual or future movements are responsible or threatening.

A sole focus on China's responsibilities, as well as China's threats, from the perspective of international relations and politics, can slip into the fallacy of oversimplification easily. It is of vital importance to understand the root of China's responsible power claim. Specifically, it is necessary to probe into the evolutions of the idea of responsibility in the Chinese context and the Western language of China's responsibility, which are the two discourses that have exerted major influence on the construction and representation of China's responsible power claim in different channels. Secondly, to discern China's actual articulation of the claim of responsible power, a systematic analysis of China's governmental policies as expressed in major political documents will be useful. Thirdly, an analysis of the representation of the claim through China's transnational media institutions can help to uncover the exact messages that China tries to disseminate to the outside world.

\section{Key Findings and Approaches}

Previous research about China's media 'going-out' project mostly state the outreach strategies of China's media first and then analyse, but not in a systematic way, the underlying political economy factors and also influences (e.g. Gorfinkel et al., 2014; Bakshi, 2011; Zhang, 2011). Only a limited number of studies have conducted media texts, production, and/or audience analysis, the three major parts of media studies (e.g. Lee, 2014; Zeng, 2010). Therefore, it is necessary to change the status quo of academic studies on China's media 'going-out' project by focusing on specific texts, production procedures, and/or audience and examine China's soft power projection in a microscopic way. In particular, to understand China's intentions and efforts to counteract the negative Western perceptions and disseminate its own benign messages, an analysis of media texts and production is essential and effective. Two exceptional studies are pointed out here. Zeng (2010) conducts a detailed discourse analysis of the news texts of CNC World in her Master thesis. It illuminates an important research perspective in assessing China's outbound communication and soft power projection. The contributors to the actual influence of a media institution, including production values, professionalism, market structure, content censorship, media ownership, and foreign investment policies, are all manifested through its content. Specifically, as to the projection of soft power through media institutions, among the three factors identified by Zhang (2008) that influence the rise of soft power, namely the power of transmission, the message conveyed, and effective communication with the audience, the message should serve as the core. This is in line with Ding's (2008) statement that the maintenance of soft power rests with its content instead of form. Thus, it 
Volume 1, Issue 1: New Directions in Media Research 2015

is proper to conduct a detailed discourse analysis of the content of China's transnational media institutions to examine how the discourse that China is a responsible power in economy is represented.

As for the analysis of media production, Lee's (2014) PhD thesis, China's soft power projection through media products in South Korea and Japan, brings fresh air into this domain. In addition to a thorough analysis of relevant materials, such as China's published statistics, local documents, government documents, and local scholarly works, the author also applied qualitative interviewing and interviewed 36 media practitioners and professionals in China to examine China's exports of cultural products. Fieldwork with media practitioners adds considerable evidence to the formulation of his arguments since it provides valuable first-hand materials. Therefore, it is important also to involve analysis of media production by interviewing relevant Chinese media practitioners and examine how they conceive the responsible power claim and represent it in media during China's media 'going-out' project.

\section{Conclusion}

China's media 'going-out' project emphasises the role of media in soft power projection. It was launched to counteract the media imperialism, and more importantly, the impugnation of China's potential threats and irresponsibility. What's more, it is, at the same time, meant to softly disseminate China's benign messages that China is a responsible power in areas like economy through its own transnational media institutions. To obtain a better understanding of the discourse of China's economic responsibilities represented through China's transnational media institutions, an analysis of pertaining media texts and production procedures is necessary and effective. In addition to the above major findings through systematic literature review, this conference paper has also located academic gaps in the representation of China's economic responsibilities discourse through its transnational media institutions. It proposes to change the status quo of academic studies of China's media 'going-out' project and its projection of responsible power discourse by focusing on relevant media texts and production procedures, on the basis of a thorough understanding of the concept of responsibility in the Chinese setting and the articulation of China's responsibility in the Western language.

\section{References}

Al-Rodhan, K.R. (2007) 'A critique of the China threat theory: a systematic analysis', Asian Perspective, 31(3), pp. 41-66. 
Volume 1, Issue 1: New Directions in Media Research 2015

Bakshi, A.C. (2011) 'China's challenge to international journalism', SAIS Review of International Affairs, 31(1), pp. 147-151.

Bernstein, R. and Munro, R.H. (1997) 'The coming conflict with America', Foreign Affairs, 76(2), pp. 18-32.

Boyd-Barrett, O. (2010) 'Media imperialism reformulated', in Thussu, D.K. (eds.) International communication: a reader. London: Routledge, pp. 139-153.

Breslin, S. (2010) 'China's emerging global role: dissatisfied responsible great power', Politics, 30(S1), pp. 52-62.

Broomfield, E.V. (2003) 'Perceptions of danger: the China threat theory', Journal of Contemporary China, 12(35), pp. 265-284.

Castells, M. (2008) 'The new public sphere: global civil society, communication networks, and global governance', The Annals of the American Academy of Political and Social Science, 616(1), pp. 7893.

Chadha, K. and Kavoori, A. (2000) 'Media imperialism revisited: some findings from the Asian case', Media, Culture \& Society, 22(4), pp. 415-432.

Chen, J. (2009) 'The practice of the Mean: China's soft power cultivation', in Li M. (eds.) Soft power: China's emerging strategy in international politics. Plymouth: Lexington Books, pp. 83-101.

d'Hooghe, I. (2010) 'The limits of China's soft power in Europe: Beijing's public diplomacy puzzle', Clingendael Diplomacy Papers No. 25. The Hague: Netherlands Institute of International Relations 'Clingendael'.

deLisle, J. (2010) 'Soft power in a hard place: China, Taiwan, cross-strait relations and U.S. policy', Orbis, 54(4), pp. 493-524.

Deng, Y. (2009) 'The new hard realities: 'soft power' and China in transition', in Li M. (eds.) Soft power: China's emerging strategy in international politics. Plymouth: Lexington Books, pp. 63-81.

Deng, Y. (2015) 'China: the post-responsible power', The Washington Quarterly, 37(4), pp. 117-132.

Ding, S. (2006) Soft power and the rise of China: an assessment of China's soft power in its modernization process. PhD thesis. Rutgers University. Available at: http://dga.rutgers.edu/wpcontent/uploads/2012/10/Ding-Soft-Power.pdf (Accessed: 10 September 2015)

Ding, S. (2008) The dragon's hidden wings: how China rises with its soft power. Plymouth: Lexington Books.

Galtung, J. and Ruge, M.H. (1965) 'The structure of foreign news', Journal of Peace Research, 2(1), pp. 64-91.

Gao, X. (2013) 'China as a 'responsible power': altruistic, ambitious or ambiguous?', International Journal of China Studies, 4(3), pp. 405-438.

Gill, B. (2007) China becoming a responsible stakeholder. Available at: http://carnegieendowment.or g/files/Bates paper.pdf (Accessed: 14 October 2015) 
Gorfinkel, L. et al. (2014) 'CCTV's global outreach: examining the audiences of China's 'new voice' on Africa', Media International Australia, 151, pp. 81-88.

$\mathrm{Hu}, \mathrm{Z}$. and Ji, D. (2012) 'Ambiguities in communicating with the world: the 'Going-out' policy of China's media and its multilayered contexts', Chinese Journal of Communication, 5(1), pp. 32-37.

$\mathrm{Hu}$, Z., Zhang, L. and Ji, D. (2013) 'Globalization, social reform and the shifting paradigms of communication studies in China', Media, Culture \& Society, 35(1), pp. 147-155.

Jiang, Z. (1997) Combine efforts for a fair and reasonable world's new order. Available at: http://new s.xinhuanet.com/ziliao/2002-03/03/content 2644576.htm (Accessed: 26 August 2015).

Jin, C. (2009) 'From 'China treat theory' to 'China responsibility theory': the change of the international public opinion environment and China's reactions', Green Leaf, 5, pp. 63-70.

Kalathil, S. (2011) 'China's soft power in the information age: think again'. [Preprint]. Available at: $\underline{\text { htt }}$ ps://isd.georgetown.edu/sites/isd/files/Kalathil Chinas Soft Power.pdf (Accessed: 8 August 201 5)

Lee, C.S. (2014) Chinese soft power through media products: its projection and reception in South Korea and Japan. PhD thesis. National University of Singapore. Available at: http://scholarbank.nus.edu.sg/bitstream/handle/10635/78937/ClaireSELeeThesis.pdf?sequence $=1$ (Accessed: 4 November 2015)

Liang, W. (2007) 'China: globalization and the emergence of a new status quo power?', Asian Perspective, 31(4), pp. 125-149.

Lye, L.F. (2010) 'China's media initiatives and its international image building', International Journal of China Studies, 1(2), pp. 545-568.

Ma, Z. (2007) 'China's responsibility and 'China responsibility theory", International Studies, 3, pp. 13.

Nye, J.S. (1990) Bound to lead: the changing nature of American power. New York: Basic Books.

Petticrew, M. and Roberts, H. (2006) Systematic reviews in the social sciences: a practical guide. Malden: Balckwell Publishing.

Ren, J. (2015) 'Dominant international public opinion environment faced by China's peaceful development: from 'China threat theory' to 'China responsibility theory', Journal of China University of Mining \& Technology (Social Sciences), 1, pp. 13-18.

Roy, D. (1996) 'The 'China threat' issue: major arguments', Asian Survey, 36(8), pp. 758-771.

Schiller, H.I. (2010) 'Not yet the post-imperialist era', in Thussu D.K. (eds.) International communication: a reader. London: Routledge, pp. 247-260.

Scott, J. and Wilkinson, R. (2013) 'China threat? Evidence from the WTO', Journal of World Trade, 47(4), pp. 761-782.

Shirk, S.L. (2007) China: fragile superpower. Oxford: Oxford University Press. 
Volume 1, Issue 1: New Directions in Media Research 2015

Sreberny-Mohammadi, A. et al. (eds.) (1985) 'Foreign news in the media: international reporting in 29 countries', Reports and Papers on Mass Communication No. 93. Paris: UNESCO.

Svensson, G. (2013) "China going out' or 'the world going in'? The Shanghai World Expo 2010 in the Swedish media', Javnost-The Public, 20(4), pp. 83-97.

Thussu, D.K. (2010) 'Mapping global media flow and contra-flow', in Thussu D.K. (eds.) International communication: a reader. London: Routledge, pp. 221-238.

Volkmer, I. (1999) News in the global sphere: a study of CNN and its impact on global communication. Luton: University of Luton Press.

Wang, Y. (2012) 'China's going-out in ten years: it is from here that the world understands China', China Press and Publishing Media Group Website, 17 October [Online]. Available at: http://www.chinaxwcb.com/2012-10/17/content 254033.htm (Accessed: 12 March 2015).

Wu, C. (2007) 'Barking up the wrong tree? The master narrative of 'China threat theory' examined', in Guo S. and Guo B. (eds.) Challenges facing Chinese political development. Lanham: Lexington Books, pp. 111-142.

Xia, L. (2001) 'China: a responsible great power', Journal of Contemporary China, 10(26), pp. 17-25.

Xu, Z. (2010) 'Analysis on the forming mechanism of China's self-role perception', Teaching and Research, 1, pp. 59-66.

Yang, Y.E. and Liu, X. (2012) 'The 'China threat' through the lens of US print media: 1992-2006', Journal of Contemporary China, 21(76), pp. 695-711.

Yeophantong, P. (2013) 'Governing the world: China's evolving conceptions of responsibility', The Chinese Journal of International Politics, 6, pp. 329-364.

Zeng, E. (2010) CNC World and China's soft power: how CNC World reports major global agenda. Master thesis. National Chengchi University. Available at: http://thesis.lib.nccu.edu.tw/cgibin/gs32/gsweb.cgi/ccd=SRwheM/fulltextstdcdr?dbid=IPXYZJTU GL\&dbpathf=/opt/fb32/db/stdc $\mathrm{drf} / \&$ fuid $=01 \& \mathrm{dbna}=$ (Accessed: 4 November 2014)

Zhang, X. (2008) 'China as an emerging soft power: winning hearts and minds through communicating with foreign publics?'. [Preprint]. Available at: https://www.nottingham.ac.uk/cpi/documents/discussion-papers/discussion-paper-35-chinaemerging-soft-power.pdf (Accessed: 9 April 2015)

Zhang, X. (2011) 'China's international broadcasting: a case study of CCTV international', in Wang, J. (eds.) Soft power in China: public diplomacy through communication. New York: Palgrave Macmillan, pp. 57-71.

Zhang, Y. and Austin, G. (2013) 'China and the responsibility of power', in Zhang, Y. and Austin, G. (eds.) Power and responsibility in Chinese foreign policy. Canberra: ANU E Press, pp. 1-20.

Zhao, L. (2010) China's identity construction as a responsible power: comment on 'China's responsibility' in west countries. PhD thesis. Wuhan University. Available at: http://www.cnki.net/KCMS/detail/detail.aspx?filename=1011065930.nh\&dbname=CDFD0911\&v 
Volume 1, Issue 1: New Directions in Media Research 2015

=MDAwNDFyQ1VSTCtmYitWdkZpemxXN3ZJVkYyNkg3TytHOWpQcjVFYIBJUjIEMzA3ekl4Vm16dDZ RWHprMm1BMUY= (Accessed: 10 June 2015)

Zhao, Y. (2013) 'China's quest for 'soft power': imperatives, impediments and irreconcilable tensions?', Javnost-The Public, 20(4), pp. 17-30.

Zoellick, R.B. (2005) Whither China: from membership to responsibility?. Available at: http://2001-2009.state.gov/s/d/former/zoellick/rem/53682.htm (Accessed: 16 June 2015).

\section{Biography}

Xin Zhao is a PhD candidate in media in Bangor University. Her research interests include international communication, soft power, and discourse analysis. This paper is a part of the literature review of her PhD project in which China's sociocultural background surrounding the term responsibility, China's policies concerning the responsible power claim, and a comparison of the representation of China's economic responsibilities in Chinese and Western media respectively are included. She thanks the China Scholarship Council-Bangor University Scholarship (CSC No. 201406330084) for financial support. She also thanks Dr Vian Bakir and Dr Andrew McStay for their PhD supervision. 
Contact author(s):

cop40c@bangor.ac.uk

\section{Contact for(e)dialogue}

General inquiries at foredialogue@leicester.ac.uk

Editorial inquiries at foreditorial@leicester.ac.uk 